\title{
A New Item in the Diet of the Kashmir Rock Agama (Laudakia tuberculata)
}

\author{
Swati Nawani ${ }^{1}$, Abhijit Das ${ }^{2}$, and Indraneil Das ${ }^{3}$ \\ Wildlife Institute of India, Dehradun, Uttarakhand 248 001, India \\ ( ${ }^{1}$ swatinawani327@gmail.com; ${ }^{2}$ abhijit@wii.gov.in)
}

3Institute of Biodiversity and Environmental Conservation, Universiti Malaysia Sarawak, 94300 Kota Samarahan, Sarawak, Malaysia (idas@unimas.my)

$\mathrm{T}$ he Kashmir Rock Agama (Laudakia tuberculata) is a saxicolus lizard with a distribution that ranges from eastern Afghanistan across northern Pakistan and India to Nepal and the Tibetan Plateau at elevations of $310 \mathrm{~m}$ to at least 5,000 $m$ in the western Himalayas (Minton 1966; Khan 2006). Its diet has been reported to include both plant and animal matter (Waltner 1991; Eremchenko and Kästle 2002). Minton (1966) reported insects taken by juveniles, which is suggestive of an ontogenetic dietary shift as has been reported in many ecologically similar large herbivorous lizards, including congeners (see Waltner 1991).

Bashir et al. (2009) examined the natural diet and reported both animals and plants in the diet of the species; plants included Brassica oleracea var. acephala (Kale), B. oleracea var. capitata (Cabbage), Solanum lycopersicum (Tomato), Lactuca serriola (Prickly Lettuce), Cynodon dactylon (Bermuda Grass), Trifolium repens (White Clover), Morus alba (White

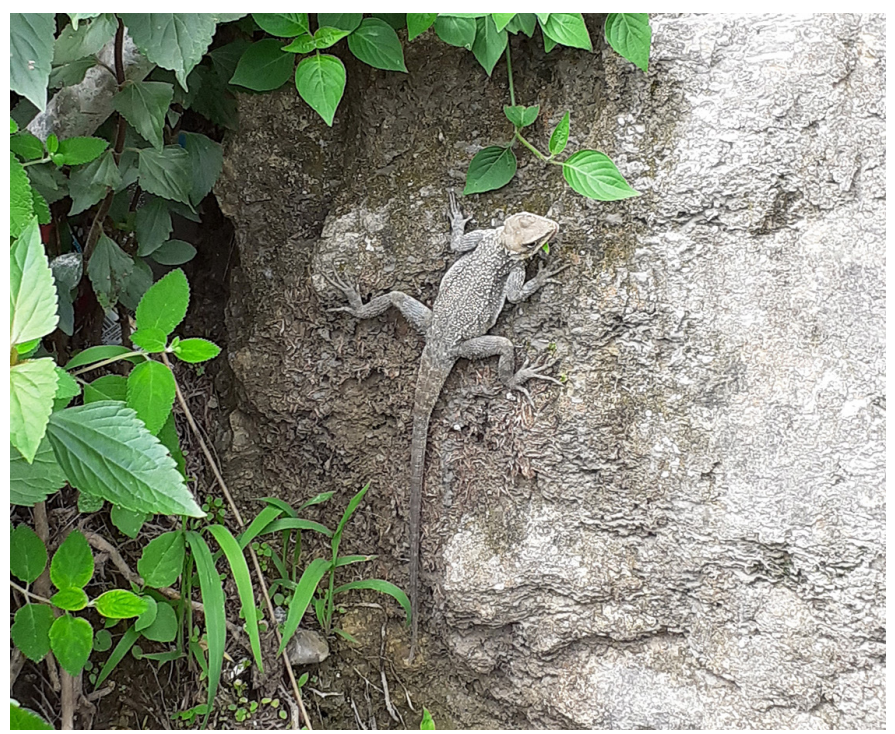

Fig. 1. An adult Kashmir Rock Agama (Laudakia tuberculata) feeding on the leaves of Panicled Foldwing (Dicliptera aff. paniculata) (Acanthaceae) outside the Benog Wildlife Sanctuary, Uttarakhand, India. Photograph by Swati Nawani.
Mulberry), and Ficus carica (Common Fig). Additionally, Lal (1991) noted that the species, presumably around cultivated areas, would feed on "tender leaves of pumpkin, squash, bottle gourd, brinjal, tomato, Zinnia, Dablia and some forest plants in nurseries"; and Vishwakarma et al. (2019) described individuals of this species feeding on flowers of the naturalized Madagascar Periwinkle (Catheranthus roseus) in a tropical moist dry deciduous forest.

At around 1430 h on 29 July 2019, we videographed an adult Kashmir Rock Agama on a rock at the edge of a road (Fig. 1) surrounded by Eupatorium sp. (Asteraceae) and Panicled Foldwing (Dicliptera aff. paniculata) (Acanthaceae). The lizard was feeding on leaves of the latter, a species that had not been recorded in the diet of L tuberculata. The locality is adjacent to human habitations outside Benog Wildlife Sanctuary $\left(30.480126^{\circ} \mathrm{N}, 78.036475^{\circ} \mathrm{E}\right.$; WGS84), Uttarakhand, India. The video footage was accessioned into the Zoology Research Collection (ZRC) of the National Museum of Singapore as ZRC [IMG] 2.462.

\section{Acknowledgements}

We thank the Uttarakhand Forest Department for permission to conduct our study (permit letter no 1236/5-6 [WII] dated 16 November 2017); WII Grant in Aid Research for funding, and G.S Rawat for identifying the food plant. Kelvin K.P. Lim provided the accession number for the video footage of the incident.

\section{Literature Cited}

Bashir, M., S.G. Mustafa, and J. Ulfat. 2009. Diet and diet choice in the common Kashmir lizard, Laudakia tuberculata: Gray. Ecology Environment and Conservation 15(2): 397-402.

Eremchenko, V. and W. Kästle. 2002. Agamidae, pp. 574-783. In: H.-H. Schleich and W. Kästle (eds.), Amphibians and reptiles of Nepal. Biology, Systematics, Field Guide. Koeltz Scientific Books, Koenigstein.

Khan, M.S. 2006. Amphibians and Reptiles of Pakistan. Krieger Publishing Company, Malabar, Florida.

Lal, O.P. 1991. Distribution, habits, habitats and feeding behaviour of common rock lizard, Agama tuberculata Gray (Reptilia: Agamidae) in Kullu Valley, western Himalayas. Journal of Entomological Research, New Delhi 15(4): 248-250. 
Minton, S.A. 1966. A contribution to the herpetology of West Pakistan. Bulletin of the American Museum of Natural History 134: 27-184.

Vishwakarma, R., D. Sengupta, L. Gomes, and A.C. Momin. 2019. Notes on Kashmir Rock Agamas, Laudakia tuberculata (Gray, 1827), from the Kalesar
Wildlife Sanctuary in northern India. Reptiles \& Amphibians 26(1): 75-76. Waltner, R.C. 1991. Altitudinal ecology of Agama tuberculata Gray in the Western Himalayas. University of Kansas Museum of Natural History, Miscellaneous Publications 83(3): 1-74. 